\title{
The polemics of making fire in Tasmania: the historical evidence revisited ${ }^{1}$
}

\author{
Rebe Taylor
}

When Jones asserted in 1971 that the Tasmanian Aborigines had dropped scale fish from their diet, he did so with corroborated archaeological evidence: he found a nonpresence of scale-fish refuse in middens past $4000 \mathrm{BP} .^{2}$ When, in 1977, he asserted that they had also lost the ability to make fire, he did so without any such evidence. Apart from the possible traces of fire left on stones that may have been used as striking flints, as suggested by Gisela Völger, there is no archaeological evidence that could reasonably exist to determine the notion positively or negatively. ${ }^{3}$ The evidence concerning whether the Tasmanian Aborigines could make fire is drawn entirely from a small number of historical sources, all of which are ambiguous. If this is the case, how did the idea gain wide acceptance and why has it survived for so long? The short answer lies in the persuasiveness and popularity of Jones' work. In his widely-read 1977 paper he controversially concluded that the Aboriginal people had chosen, imprudently, to drop scale fish from their diet. ${ }^{4}$ Jones went on to propose that the Tasmanians had also lost a range of arts and tools such as hafted axes and boomerangs because, being a small population isolated for millennia, they had eventually degenerated to a culture so simple that Jones wondered if they had been 'doomed to a slow strangulation of the mind'. ${ }^{5}$ These words became famous with repeated reference, but it was their resonance with the hugely successful film The Last Tasmanian, in which Jones appeared as narrator, that made them (and him) so well-known and so controversial.

Perhaps the most provocative aspect of Jones' degeneration thesis was the idea that the Tasmanian Aborigines had lost the ability to make fire. 'Fire was carried ... in

1. This article is the second of a two-part examination of the historiography of Tasmanian Aboriginal people. The first article, 'The polemics of eating fish', published in volume 31 (2008) of this journal, questioned the certainty archaeologists have held for the proposition, first suggested by Rhys Jones in 1971, that the Tasmanian Aboriginal people stopped eating fish with scales about 3000 to 4000 years ago. This article re-examines another of Jones' widely accepted assertions: that Indigenous Tasmanians were unable to make fire.

2. In light of the adage 'absence of evidence is not evidence of absence', the term 'non-presence' is considered by archaeologists to be more meaningful and accurate in a context such as this.

3. Völger 1973: 61.

4. Jones 1978: 44-46; Jones 1987a: 38; Jones 1977a: 196; Jones 1977b: 343.

5. Jones 1977a: 196-197, 202-203. 
smouldering slow burning fire-sticks', Jones wrote, 'but the Tasmanians did not know how to make it': if their sticks went out, they had 'to go to their neighbours for a relight'. ${ }^{6}$ In making this statement, Jones relied on a note by NJB Plomley in the edited journals of GA Robinson: 'the Tasmanians seem to have had no artificial means of producing fire. They had to keep a fire constantly alight and, if it was extinguished, had to obtain fire from other natives. ${ }^{7}$ Plomley in turn was relying on the one entry in Robinson's diary from which such an interpretation could be made. It is from 28 December 1831, written as Robinson was making one of his five epic treks across Tasmania with 'his mission' Aborigines:

As the chief always carries a lighted torch I asked them what they did when their fire went out. They said if their fire went out by reason of rain they [were] compelled to eat the kangaroo raw and to walk about and look for another mob and get fire of them. They must give fire and sometimes they would fight afterwards. MANNALARGENNA said that the two men in the sky first gave the natives fire, that they stood all round. WOORADY said PARPEDER gave fire to the Brune natives. ${ }^{8}$

In the years since Jones' pronouncements on fire, the claim has been widely repeated: ${ }^{9}$ by Lyndall Ryan in The Aboriginal Tasmanians; by Vivienne Rae-Ellis in Trucanini: Queen or Traitor? ${ }^{10}$ Tim Flannery's 1994 book, The Future Eaters, restated the claim, citing Rae-Ellis; ${ }^{11}$ and Jared Diamond's 1993 article 'Ten thousand years in isolation' stated that 'most archaeologists suspect that [the Tasmanians] had no means of kindling [fire]'. ${ }^{12}$ Most recently, Keith Windschuttle, in The Fabrication of Aboriginal History, writes that the 'colonists were astonished to observe [the Aborigines] could not make fire, a skill that even Neanderthal man had mastered'. ${ }^{13}$ The idea has broad appeal even beyond books: while holidaying in the Bass Strait in 1996, another tourist told me that the Tasmanian Aborigines were 'so backward' that 'they couldn't even make fire'.

\section{Jones 1977a: 196}

Plomley 1966: 225.

Plomley 1966: 567.

. There may have been some wider currency for the idea the Tasmanians may not have known how to make fire before Plomley published Friendly Mission: a pamphlet published in 1960 for visitors to the Tasmanian Museum and Art Gallery stated that the Aborigines 'usually carried fire with them, but there is no direct evidence to show how they produced fire'. Plomley appears to have taken this lack of evidence a step further when he asserted that they had no means to make fire at all (Bryden 1960: 3). Interestingly, Jones did not repeat the idea the Tasmanian Aborigines could not make fire in his 1978 chapter, 'Why did the Tasmanians stop eating fish?', despite recapitulating all the other aspects of his regression theory, though in 1987 he stated 'they could not make fire' (Jones 1987b: 30).

10. Lyndall Ryan no longer considers it reasonable that the Tasmanian Aboriginal people could not make fire (Ryan, personal communication with the author, 4 November 2008; Ryan 1996 [1981]: 11; Rae-Ellis 1981: 8). Neither Ryan nor Rae-Ellis reference Jones; Ryan has no reference and Rae-Ellis references Plomley 1966: 567. However, considering their books were published shortly after Jones' work became public, it was arguably Jones who influenced both scholars to make their statements on fire making.

11. Flannery 1994: 264-270. Flannery contextualises the claim that the Tasmanian Aborigines could not make fire within a detailed description of Jones's thesis of regression in detail from the dropping of fish, bone awls and other wooden implements, but with no reference to Jones. Instead Flannery references Diamond 1993. 
While the idea that the Tasmanian Aborigines could not make fire became most widely repeated from the late 1970s, there were writers in the 19th century who also considered it true. James Backhouse, following his journey to Tasmania from 1832 to 1838, wrote that the Aborigines 'had no artificial method of obtaining fire', 14 and Thomas Dove, after talking to Aborigines at the Flinders Island settlement, concluded in 1842 that:

their memory supplies them with no instances of a period in which they were obliged to draw on their inventive powers for the means of resuscitating an element so essential to their health and comfort as flame. ${ }^{15}$

James Calder (quoted by Roth) claimed in 1874 that the Aborigines of Tasmania 'were ignorant of any method of procuring fire'. ${ }^{16}$ In his 1878 edition of Researches into the History of Mankind, Tylor reported that Joseph Milligan, who compiled a significant vocabulary of Tasmanian Aboriginal words in 1859, thought, in Tylor's words, 'the Tasmanians never produced fire by artificial means at all' ${ }^{17}$ Even though Roth and Tylor quote such opinions from early writers, they did not agree with them. In the preface to the second edition of Roth's The Aborigines of Tasmania Tylor defined the 'rude savages' of Tasmania as 'representatives of the immensely ancient Palæolithic period', but he thought any of the 'accounts of finding fireless tribes are of a highly doubtful character $^{\prime}{ }^{18}$ Roth thought the idea just as fantastic; he introduced his quotations of Calder, Backhouse and Dove with the exclamation 'at one time, the natives were said not to have known the art of making fire! ${ }^{\prime 19}$ Tylor and Roth were unconvinced by these writers because they were aware of a plethora of available evidence that suggested Tasmanian Aborigines could make fire.

\section{Early evidence of fire making}

The various accounts of fire making in Tasmania describe two main methods: a flint stone that struck a spark and the friction of two pieces of wood. Most of the earliest references to Tasmanian fire making describe the 'percussion method'.

12. Diamond 1993: 50. Diamond, like Flannery, details the dropping of fish, bone awls and other tools but only quotes Jones on his theory of isolation-induced cultural loss so as to criticise him as 'degenerationist' (1993: 55). Diamond reiterates Jones' thesis of cultural regression but creates the impression that the thesis of Tasmanian isolation is his own. Further, the editor of Discover, Paul Hoffman, included, on p. 4 of the same edition of the magazine, a preface to Diamond's article headed, 'The Tasmanian paradox', without any reference to Jones' 1977 chapter of the same title.

13. Windschuttle 2002: 377-378. Windschuttle references Robinson's diary entry of 28 December 1831 and also summarises Jones's thesis on the cessation of fish eating, loss of tools and the theory of cultural regression, footnoting his PhD thesis and his 1977 and 1978 chapters.

14. Roth 1899: 83; Backhouse 1843: 99.

15. Roth 1899: 83; Dove 1842: 250.

16. Roth 1899: 83.

17. Tylor 1964: 249-250.

18. Roth 1899: vii; Tylor 1964: 249-250. While 'Fire, cooking and vessels' was originally published as chapter 9 in Researches in the History of Mankind, in the 1964 edition it is presented as an appendix. Editor Paul Bohannan writes that that this chapter is 'still one of the best general summaries on its subject' (Tylor 1964: v).

19. Roth 1899: 83. 
In 1773, during the du Fresne expedition, Tobias Furneaux reported finding a stone kept in a basket 'to strike fire with and tinder made of bark' at Adventure Bay, Bruny Island..$^{20}$ Lieutenant George Mortimer - on Cox's exploration of Maria Island (north of Bruny Island) in 1789 - wrote of finding 'a few flints and stones and a little dried grass; from which circumstance I conclude they produce fire by collision' ${ }^{21}$ Similarly, JJH La Billardière in 1792, on the second French expedition led by Bruny D'Entrecasteaux, found baskets in an abandoned campsite at Recherche Bay 'filled with various pieces of silex, wrapped up in the bark of a tree, as soft as good tinder', from which he concluded, 'the method which these savages employ to procure fire is, to strike two pieces of silex one against the other' ${ }^{22}$ On the same expedition, Louis Ventenat described small baskets containing tinder and flints and a 'silex' with which the Aborigines ignited a 'very dry bark', and further identified two soft barks used as tinder. Joseph Raoul also found 'baskets full of stones for striking fire', while La Motte du Portail described a 'leather bag' that contained 'pebbles, by the striking of which they procure fire, using a moss instead of tinder' ${ }^{23}$

In 1792 George Tobin, an officer on Captain William Bligh's Providence, found in an empty hut at Adventure Bay 'two small pieces of white stone, very different from any about Adventure Bay, and soft bark wrapped up carefully in grass'. Tobin concluded that 'with this stone and bark natives probably strike their fire', ${ }^{24}$ while Bligh remarked that he could not find a tinder that would ignite, when he tried this method. Considering his lack of experience with these materials, this is perhaps not surprising. ${ }^{25}$

Some 40 years after the first explorers came to Tasmania, GA Robinson wrote in his journal on Bruny Island, that he had 'obtained a stone' used by the 'Brune natives with which they sharpen their waddies and by means of which they strike fire. They call it My.rer' ${ }^{26}$ Völger observes that this word may correspond to the words Milligan records in his 1859 vocabulary for 'flint' - Mungara or Mora Trona from Bruny Island, Recherche Bay, Mount Royal and south of Tasmania and Trowutta from the Aboriginal people from Oyster Bay to Pittwater. ${ }^{27}$

Roth was unconvinced by the early explorers' conclusions: he was 'very certain' that these observers 'mistook the so called "flint" implements or stone hatchet for real flint for striking fire' and concluded that the percussion method of fire making was 'unknown to them' ${ }^{28}$ Plomley, in 1983, too remained unconvinced by the early explorers' conclusions, pointing out that they were 'no doubt influenced by their own

20. Plomley 1983: 201.

21. Roth 1899: 83; Plomley 1983: 75, 188, 201. Note that while Plomley attributes this quote to Cox, Roth attributes it to Mortimer.

22. Silex is a kind of quartz or gunflint (La Billardière 1800: 127; Plomley 1983: 201).

23. Plomley 1993: 272.

24. Giblin, 1928: 98; Völger 1973: 60-61.

25. Plomley 1993: 271.

26. Plomley, 1966: 113.

27. Völger, 1973: 60-61; Plomley, 1976: 413. Having studied these words for 'flint', John A Taylor concludes that 'the linguistic evidence quite independently of the ethnographic records establishes that the percussion was used' by the Tasmanian Aborigines. Taylor sees parallels between Tasmanian words and Victorian Aboriginal words, his thesis being that ancient migration patterns linguistically link the two communities (Taylor 2003).

28. Roth 1899: 83, lxxxviii. 
flintlock arms' ${ }^{29}$ Plomley further disputed Robinson's find of the 'my.rer' stone, writing in a footnote in Friendly Mission that it was 'an error' made 'due to Robinson's inexperience' or 'due to misunderstanding what he was told'. ${ }^{30}$ In 1993, however, Plomley revised his earlier conclusions about the percussion method and could now say that the early explorers' references made 'an impressive record' and that the stones were clearly regarded by the Aboriginal people as precious, being wrapped in bark and stored in specially-made baskets. ${ }^{31}$ Even Fritz Noetling, who considered the Tasmanians to be at the 'Archaeolithic' [pre-Palaeolithic] stage of evolutionary development, had concluded they were able to make fire 'by striking the piece of iron pyrites against a siliceous stone' 32

Völger points to some of the stone artefacts in the Westlake Collection in the Pitt Rivers Museum for which 'neither the material nor the form has been defined', but which 'sometimes show traces of use and fire'. Considering both the linguistic evidence and the fact the writers all drew the same conclusion independently, Völger concludes it is 'very likely that the percussion technique was the Tasmanian method of lighting fire'. She further notes that Aboriginal use of the percussion method in other parts of Australia. Philip Jones identifies detailed evidence for the method in South Australia, New South Wales and Central Australia and notes that Völger's linguistic findings 'suggest that the percussion technique was known in Tasmanian'. ${ }^{33}$ Along with anthropologists Berndt, Calley and Mountford, Jones further considers it likely that the percussion method preceded the friction methods, especially since it appears in Dreaming stories throughout southern Australia. ${ }^{34}$

It may be, however, that the percussion method was not used across all of Tasmania since all observations, including the linguistic evidence, about this method come from the island's south-eastern corner, particularly the D'Entrecasteaux Channel. ${ }^{35}$

\section{The friction method}

The earliest reference to the friction method was noted in 1793 by Louis Ventenat on the D'Entrecasteaux expedition, who wrote that the Aborigines 'make fire by rubbing together two pieces of wood one against the other' ${ }^{36}$ Gott considers that Ventenat's description might be an eye-witness account, since it was preceded with a detailed description of meeting with a group of Aborigines. ${ }^{37}$ Indeed, unless they had somehow

29. Plomley, 1983: 201. Plomley had previously noted that while there were reports that the Tasmanians used both the percussion and friction methods that 'none of these methods of making fire can be proven for the Tasmanians, and it is nearly certain that in fact they could not produce fire' (Plomley 1977: 25).

30. Plomley, 1966: 225.

31. Plomley 1993: 272.

32. Noetling 1907: 2, 5: Gott 2000: 10.

33. Jones 2008: 10-16; Völger 1973: 6.

34. Jones 2008: 10-11.

35. Gott 2002: 653. Philip Jones suggests that the percussion method may possibly have preceded the friction methods. He notes that the percussion method was used 'in Northern New South Wales, Flinders Ranges, Lower Murray regions of South Australia, isolated localities in Victoria and possibly in Tasmania' (Jones 2008: 10, 13-14).

36. Plomley and Piard-Bernier 1993: 365.

37. Gott 2002: 652-653. 
shown him, how else would Ventenat know this was the way they made fire? Thus, it is possible that Tasmanian Aborigines in the south - where the D'Entrecasteaux expedition was confined - may have used both the percussion and friction methods to make fire. Ventenat in fact noted both.

Subsequent friction method references date from the 1840s. RH Davies, in 1846 stated: 'I have been informed that they obtained [fire] by rubbing around rapidly in their hands a piece of hard pointed stick ... inserted into a notch in another piece of dry wood'. Henry Melville, in 1851, wrote that the Tasmanian Aborigines made fire 'from the friction of a stick, rapidly moved between the palms of their hands, with the point embedded in a piece of soft bark'. James Bonwick, in his 1870 book Daily Life and the Origins of the Tasmanians, asserted 'we have abundant evidence that they did know how to produce artificial flame'. Bonwick presents a description, told to him by a bushranger that 'the Natives' made fire from creating 'friction' between 'two pieces of grass-tree stem'. One stick was twirled in the groove of the other, into which was also placed 'some soft down of the inner bark of trees, called balls-wool' and some 'powdered charcoal' $^{38}$ In a letter written to the Royal Society of Tasmania in 1873, James Scott stated that his brother Thomas, a former assistant Surveyor-General and resident in Tasmania from 1820, told him the Aborigines knew how to light fire 'by friction of two pieces of wood' $^{39}$

These references are all cited by Roth, who ultimately doubted their reliability, as, subsequently, did Jones and Plomley. This may explain why Windschuttle wrote in a footnote in his The Fabrication of Aboriginal History that 'the inability to make fire has long worried many observers', before adding 'for several implausible rationalisations, see Roth'. ${ }^{40}$ Roth had not questioned these sources in his first edition (1890) of The Aboriginal Tasmanians where he considered the Aborigines had been able to make fire 'by means of two quite distinct methods': the percussion and friction methods ( $p$ 96). In his second (1899) edition, however, Roth reassessed most of his findings on fire making.

Roth had featured illustrations of two wooden fire drills in his first edition. These he presumed had been collected by GA Robinson in Tasmania. One had featured in John Lubbock's 1863 Pre-historic Times, prompting Tylor to conclude that the Tasmanian Aborigines made fire by this method. ${ }^{41}$ The 'hearth' of this drill (the piece of wood into which a straight stick was turned) is now housed in the Fuller Collection in Chicago. The second drill - the only complete fire drill provenanced as Tasmanian in existence - is housed in the Pitt Rivers Museum. When Roth carried out his research for his second edition, he became aware that, like several other artefacts collected by Robinson, these fire drills may have in fact been collected by him in Victoria. ${ }^{42}$ Gaye Sculthorpe and Plomley share these doubts, both noting that when Robinson was in Victoria, he wrote in his journal on 13 May 1840: 'I observed for the first time how

38. Roth 1899: 83; Bonwick 1870: 20.

39. Roth 1899: 83; Scott 1873: 24-25.

40. Windschuttle 2002: 377.

41. Tylor 1964: 253. Lubbock 1878: 439-440. Since much of Lubbock's brief section on the Tasmanian Aborigines is devoted to quoting Dove's assertion that they were unable to make fire the illustration of the drill is left quite unexplained. Plomley observed that Lubbock failed to respond to Robinson's letter warning him not to trust Dove's observations (Plomley 1962: 12). 
natives in their original state get fire by friction from two pieces of wood', suggesting he had never seen this in Tasmania. ${ }^{43}$ While Robinson may not have seen fire being made in Tasmania, he did record, from the Port Sorell and Ben Lomond people of northern Tasmania, the phrases meaning 'to light (make) a fire': mo.yer.way.ne' and 'per.le.we.pe.nup.ple'. Further, Plomley notes that in 1865-1866 Robinson had written to a Dr John Davy explaining 'the manner employed by the Tasmanians to produce fire', but from these descriptions Davy 'could only infer that the method was 'by friction' ${ }^{44}$ Sculthorpe also explains that a very similar fire drill collected by Robinson, and now in the Museum of Victoria, was tested in 1956 and it was found that the hearth of the drill 'agree[d] well' with a species of bush that did not occur in Tasmania. ${ }^{45}$

In 1899 Roth wrote to James Backhouse Walker, a Hobart solicitor and grandson of George Backhouse, about the fire drill in the Pitt Rivers Museum. Walker, a respected and published expert in Tasmanian Aboriginal history, had, since 1891, been Roth's primary informant and guide for the changes to the new edition of his book. Walker agreed that there was indeed 'a grave doubt' the drill was Tasmanian, but warned 'there is surely sufficient evidence that the Blacks were acquainted with some method of producing fire, though the exact apparatus used appears to be now beyond discovery' ${ }^{46}$ Indeed, there are relatively few original wooden Tasmanian Aboriginal artefacts in museum collections; the absence from any such collection of a definitivelyTasmanian fire drill does not signify such an artefact was never used or that the Tasmanians could not make fire.

Unlike his grandfather, Walker considered the idea the Tasmanian Aborigines had been unable to make fire absurd. In 1899 he wrote to Roth about a recent article in the Spectator that 'ventured the astounding statement that there were races of mankind, "like the Tasmanians", who ... were ignorant of the use of fire!' But he added that the Spectator occasionally went 'wildly astray, and sometimes falls an easy victim to a hoax'. ${ }^{47}$ Further to this, Walker sent two descriptions he had gathered on Aboriginal fire making. The first was from Edward Cotton of Kelvedon (whom Westlake later met)

42. In his Appendix H, 'Tasmanian Fire Sticks', added after The Aborigines of Tasmania went to press, Roth (1899: 1xxxix) claims this drill was given to Barnard Davis by Dr Joseph Milligan who had had charge of the mission at Oyster Cove, Tasmania. Roth considered that Milligan 'knew nothing of the Aborigines until 1847' and therefore 'his presentation of the fire drill to Barnard Davis as a Tasmanian implement does not prove the drill to have been Tasmanian'. However, Plomley considers it unlikely that Milligan presented the drill to Davis, but that it came directly from Robinson (Plomley 1962: 11-12). Roth (1899: 1xxxix) illustrates Robinson's unreliability in discerning Victorian from Tasmanian Aboriginal artefacts with the example of a ground stone tool presented to Barnard Davis by Robinson as Tasmanian, but later concluded by EB Tylor as Victorian.

43. Sculthorpe 1990: 35-36; Plomley 1962: 11-12. Gott agrees that the drill sets 'cannot be unequivocally attributed to Tasmania' (Gott 2002: 654).

44. Plomley 1976: 225; Plomley 1962: 11-12.

45. Sculthorpe 1990: 34-36. Sculthorpe notes that Westlake's reports of fire drills being used in Tasmania 'suggest caution in attributing a southeastern Australian provenance for all these specimens' but considers that the form of the fire drill 'no doubt' originated on the mainland and was possibly introduced to Tasmania by Port Phillip or Sydney Aborigines.

46. Walker, letter to Roth, 16 May 1899. Walker reiterated the plausibility of the stick-and-groove method and refers to Roth's Appendix H (Walker 1900: 5).

47. Walker, letter to Roth, 16 May 1899. 

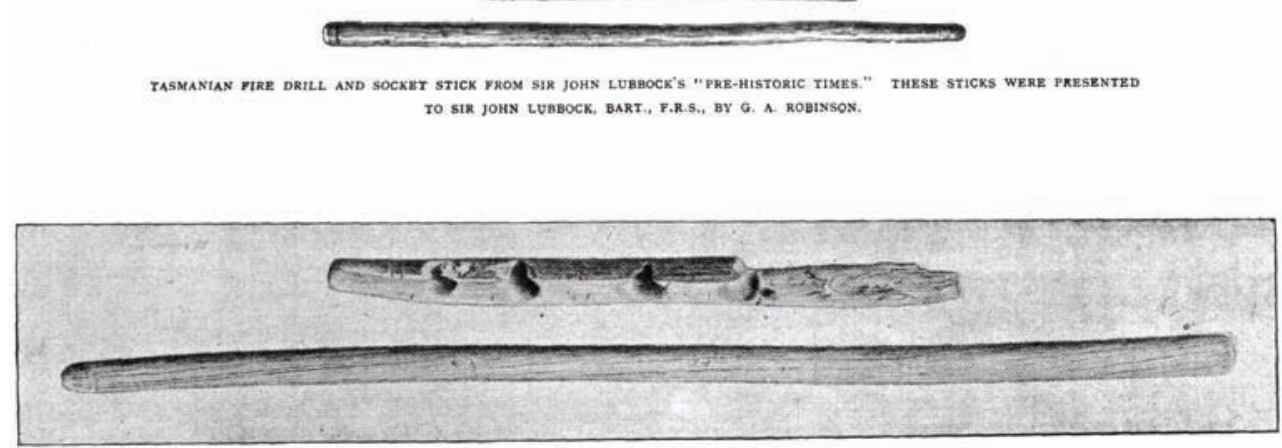

TASYANIAN YIRE DRILL AND SOCKET STICK IN THE PITT-RIVERS' MUSEUY, OXFORD PRESENTED BY GENERAL. PITT-RIVERS, P.R. ., WHO OBTAINED THEM PHON THE COLLECTIOS OF BARNARD DAVIS.

$$
\text { (See Appendix } H \text { ). }
$$

Tasmanian fire drills as featured in Ling Roth 1899, facing page 83. The lower drill featured is still housed in the Pitt Rivers Museum.

recorded in about 1896. Walker explained that 'it may be relied on' since Cotton had lived 'from childhood among the old settlers' and was a man of 'keen observation, retentive memory, vigorous intellect, and is thoroughly trustworthy'. ${ }^{48}$ Cotton told Walker how his elder brother had witnessed an Aboriginal man making fire:

He first found a dry log or dead trunk ... next he collected ... a quantity of dry wood dust ... [with which] he filled the crack in the log. He then chose a dry stick, and shaped it a little at one end until it roughly fitted the crack ... he then rubbed it vigorously and firmly up and down [until] ... the dust began to smoke and eventually took fire. ${ }^{49}$

Walker later sent Roth a second description from Mr Rayner, a similarly-aged settler, from the Derwent Valley whose account, Walker noted, 'agrees with that of ... Cotton': ${ }^{50}$

A piece of flat wood was obtained, and a groove was made the full length in the centre. Another piece of wood about a foot in length with a point like a blunt chisel was worked with nearly lightning rapidity up and down the groove till it caught in a flame. As soon as the stick caught in a blaze, a piece of burnt fungus, or punk ... was applied ... My father has seen them light it. The piece in the groove, he said, was hard, the other soft. ${ }^{51}$

48. Walker, letter to Roth, 10 June 1896.

49. Roth 1899: 83-84.

50. Walker, letter to Roth, 20 May 1998. A copy made by Walker of Rayner's letter to him, including this quote, is in 'Various Manuscripts XXVV' of Ling Roth, Henry 1919: 'The Aborigines of Tasmania: Papers ...'.

51. Roth 1899: lxxxxviii. 
While Roth noted that these accounts appeared to be more detailed variations of the descriptions from Melville, Davies and Bonwick, he considered that only these firsthand memories of older settlers had the capacity to 'carry us back to the early part of the century when the natives were still roaming about the country' ${ }^{52}$ Roth summarised from the available evidence that the Tasmanian Aborigines appeared to have had three methods by which to light fire: stone and flint, a fire drill and the 'stick-and-groove' method (as suggested by Cotton and Rayner). But, considering it was 'incredible that a race so low in culture could have known and used three methods', and since Roth deemed most the sources unreliable, he concluded that the Tasmanians knew only of the friction 'stick-and-groove' technique. While Roth doubted most of the evidence, he never doubted that the Tasmanian Aborigines could make fire. ${ }^{53}$

\section{The Westlake evidence for fire making}

The greatest body of evidence for Tasmanian fire making is contained in the Ernest Westlake papers. ${ }^{54}$ Of the 95 people Westlake noted conversations with in Tasmania, 27 recounted, in varying detail, methods by which the Aborigines made fire. They often echo earlier historical accounts of both the percussion and friction methods. The evidence for the percussion method is sparse and contrary relative to the friction method, but, it is significant that sources for the former come from southern Tasmania - where that method was first recorded by French and English explorers.

In 1910, Mrs Imms, of the D'Entrecasteaux Channel, told Westlake that she thought the Aborigines got fire 'from two flints [that is flint and steel]' and 'used a piece of punk one side of which was burnt and the spark would ignite that'. ${ }^{55}$ Is it possible that after settlement Aborigines began to use steel in what was already an established method with stone ${ }^{56}$ Mrs Hughes, also of the Channel, told Westlake she thought that the Aborigines had used two pieces of wood to start fire, but that this was 'before [they] used steel', suggesting that the friction method had come first. Reverend Atkinson, who had spent much time with the Aborigines at the nearby Oyster Cove Mission, told Westlake that fire was 'certainly not made with flint and steel. I expect would be rubbing', but he admitted, 'I don't know'. 57

The confusion over the methods may be due to several factors. The percussion and friction methods may both have been used in southern Tasmania. Aborigines from different parts of Tasmania arriving at the mission at Oyster Cove after 1847 may have brought together varying regional fire-making methods, which by then may also have

\footnotetext{
Roth 1899: 1xxxix.

Roth 1899: 1xxxix.

For details of the Westlake Papers, see Part 1 of this paper (Taylor 2007: 1-3).

55. Westlake 'Notebook 6': 36 . The reference to 'punk' being used as tinder is common in Westlake's interviews and other sources. It is either rotten wood, or a fungus growing on dead wood. Mrs Sarah Miller told Westlake that 'punk' was used along with flint and stone to make fire and explained: 'punk is a white fungus in sheets' (Westlake 'Notebook 6': 114-115). Also, Mr Rayner informed James Backhouse Walker that 'burnt fungus, or punk, as it is generally termed ... would keep alight' (Roth 1899: lxxxxviii). Sylvia Hallam notes how Aboriginal women in Western Australia carried small Banksia cones or a 'dry white species of 56. Gott 2002: 653

57. Westlake 'Notebook 2': 21 (emphasis in original).
} 
been adapted to different living conditions and contact with different cultures. Plomley, however, considered the D'Entrecasteaux testimonies to be significant because they witnessed Aboriginal people living at Oyster Cove after the mission was moved there and because it was a region 'where there was less aggression between settler and Aboriginal' early in the colonial period. ${ }^{58}$

Many of Westlake's interviewees described the friction method in ways similar to Cotton and Rayner, in particular the Aboriginal Islanders. At Killikrankie Bay, Flinders Island, Harry Armstrong told Ernest Westlake that the Aboriginal Tasmanians made fire by a stick worked in the groove of another piece of wood. He 'has tried it', wrote Westlake. The more senior Philip Thomas told Westlake that 'I have seen them making fires by rubbing pieces of wood together. I used to watch them doing it'. Thomas could also explain the process in detail: the stick was held at about an angle of 45 degrees, and also trimmed to that angle 'so as to fit in the groove'. 'Very fine powder like the ashes from a pipe' is placed into the groove, and 'turn black and catch fire very quickly'. The 'best wood' for this was 'the top of the old man grass tree, with a piece growing out of the top like a kangaroo's tail', which can 'serve [as] both sticks'. ${ }^{59}$ This description has echoes with Cotton and Rayner's 'stick-and-groove' method and also with Bonwick's reference to the use of grass tree and charcoal to make fire. The fire drills collected by Robinson appear to be made from grass tree, the drill being a harder wood and the hearth a softer, pithy, wood. ${ }^{60}$ According to Philip Jones, grass-tree stems were also used by Aborigines in Western Australia, South Australia, Queensland and Victoria. Jones further notes that 'the grass-tree generated its own tinder as it worked deeper, bringing the powdered or triturated wood to the surface'. ${ }^{61}$

Philip Thomas indicated to Westlake that both the fire-drill and the stick-andgroove methods were used by his traditional ancestors, explaining that fire could be made not only by rubbing, but also 'produced by twirling the stick between the palms of the hands like lightning'. Thomas added that 'one person will do this', suggesting that the other method required at least two people. But both techniques were practised, he said, 'using the same wood'. Thomas then said to Westlake, 'I saw them making fire from rubbing wood together before they were on Flinders'. ${ }^{62}$

On Cape Barren Island, Henry Beeton told Westlake he had 'seen some of the old sealers twirling sticks to show us youngsters how the natives used to get the fire in Tasmania'. Here it seems that the white sealers had passed on traditional knowledge from their Aboriginal partners, a possible indication of their cultural integration. Like Thomas, Beeton explained that fire was made with the 'old man grass tree' - the 'piece of wood ... like kangaroos tail growing out of the top'. This was a 'sort of pithy wood', he described, 'with a hardish shell on the outside'. A 'hard stick' was placed into the 'spongy stuff' and 'worked till pith kindled' by 'twirling the stick with the palms of the

58. Plomley and Piard-Bernier 1993: 270.

59. Westlake 'Notebook 3': 87.

60. The method of fire making Robinson noted in Victoria in 1840 corresponds very closely with the descriptions by Cotton and Rayner, including the type of wood, the addition of 'charred' powder and the action used (see Sculthorpe 1990: 35).

61. Jones 2008: 17 .

62. Westlake 'Notebook 3': 87-88. 
hand'. Notably Beeton did not refer to the stick-and-groove method, as Thomas had. While Thomas described using 'ashes from a pipe', Beeton said that a 'dried sap' from a 'particular kind of tree' was also used to help 'starting fires' and that punk was used to take the fire out of the worked hole. Beeton also said that 'tringinabiddy' was the 'small brush wood' used for kindling, and 'parteroly' was 'any sort' of fire, 'as long as it blazes' ${ }^{63}$ Notably, variations of this word appear in other vocabularies: GA Robinson recorded 'par.tro.ler' and 'Par.trow.ler' and Rev James Norman, who lived in Tasmania from 1827 to 1868, included the word 'partroller' for fire. Norman also added in brackets after this word: 'the natives in the interior obtain a fire by rubbing together two pieces of wood - one green and one dry - till the wood ignites by friction' ${ }^{64}$

There were many non-Aboriginal Tasmanians who could tell Westlake something of how they thought the Aborigines had made fire using the friction method, and Westlake recorded descriptions all over the state. Henry Gardam told him that the Aborigines 'used to make fire with the grass tree'. He said that while he had not seen the 'Blacks', make fire, he had seen the half-castes 'split tail of the grass tree and holding one piece in each hand rub the two together' ${ }^{65} \mathrm{JW}$ Graves, a Hobart solicitor, said he thought the Aborigines had got a 'piece of dried grass tree' and 'a stick or spindle' of the same wood and would 'twirl it'. While he said he had seen Aborigines do this in South Australia in 1847, he claimed that 'halfcastes have told me that the same was used in Tasmania'. ${ }^{66}$ GW Knight, the Cape Barren Island school master, told Westlake he knew a man named Pinnington who had told him that 'somewhere around Ross', he had seen the Aborigines 'make a hole in a piece of wood' and with sticks 'sharpened ... almost to fit it ... twirl it with their palms' ${ }^{\prime}{ }^{67}$

While Knight referred to Aborigines twirling a fire-drill, others referred to the stick-and-groove technique. In the D'Entrecasteaux Channel, Mr Benbow told Westlake, 'I have seen the natives at [Oyster Cove] get fire by rubbing two pieces of wood together'. He said they got a 'plane surface with a little groove in it' and then, with a 'pointed stick ... rub it to and fro'. It was a method he and a mate had tried themselves when 50 miles 'up the Gordon' on the West Coast when their matches had got wet. ${ }^{6}$ Fysh, of Plenty, told Westlake his father had seen the Aborigines make fire using '2 pieces of wood and a grove [sic] working backwards and forwards like lightning'. ${ }^{6}$ Fred Collis, a Flinders Island farmer from 1871, also told Westlake that he thought the Aborigines had made fire with a 'soft piece of wood and another piece to push forward and pull back' ${ }^{70}$ In Launceston, Mrs Charles Smith told Westlake the Aborigines made fire working one piece of wood in the groove of another. ${ }^{71}$

63. Westlake 'Notebook 3': 76, 82-84; Westlake 'Notebook 4': 22 (emphasis in original).

64. Norman 1910: 333-342. Plomley lists further variations for the word par.tro.ler from a range of sources (Plomley 1976: 225).

65. Westlake 'Notebook 4': 90.

66. Westlake 'Notebook 3': 67.

67. Westlake 'Notebook 3': 89-90.

68. Westlake 'Notebook 2': 36 .

69. Westlake 'Notebook $2^{\prime}: 25$.

70. Westlake 'Notebook 3': 92.

71. Westlake 'Notebook $4^{\prime}$ : 101. 
Thomas Riley, formerly of Carlton, where his grandfather had settled, said he remembered Charley and Shinall, two Aboriginal men who 'told me and showed me how their people got fires'. They would 'rub the stick (pointed stick) backwards and forwards ... while the other pounds charcoal and puts it in the groove'. ${ }^{72} \mathrm{Mr}$ Blyth in the Channel recalled, in 1847 - when the Aborigines were brought to Oyster Cove and he was nine or ten years old - being told how the Aborigines were seen making fire by placing a spear in hard wood and 'two or three would twirl it in their hand', which he called the 'old way of getting fire'. The other way was to simply work a pointed stick in a groove. ${ }^{73}$ Riley also said Charley and Shinall's method took two men. Is it possible that this 'old way' had been recently adapted into a one-person variation?

Both Beeton and Rayner (the latter in Roth) thought that 'punk' was used to catch the fire made in the groove. Fanny Cochrane Smith's son, Frederick, told Westlake that the "inner part of stringy bark was used to ignite fires and was called "bulls" wool' ${ }^{74}$ This corresponds with Bonwick's description of fire being captured in 'some soft down of the inner bark of trees, called balls-wool'. Also in Launceston, William Twelvetrees, the government geologist, informed Westlake that Edward Cotton - the same man quoted by Roth - had told him that the 'Aboriginals produced fire by rubbing a pointed stick in cleft [of?] honeysuckle wood'. He said they 'proby [sic] make a groove in it', into which they put in a 'powder taken from below the bark' - or 'inner bark' - of the 'white gum tree'. ${ }^{75}$ Mrs Holmes in Devonport told Westlake that her 'Father has often seen them rub two sticks' to get fire, and that they used 'a bit of fluffy stuff to ignite' it. $^{76}$ Thomas Dunabin of Bream Creek said that the Aborigines 'made fire with two sticks, rubbing a hard stick on a soft piece till it made a groove and the fluff caught fire'. 77

There are also several descriptions given to Westlake of the friction method that have less detail. Mrs Elmer, who claimed to have personally known the Aborigines of Oyster Cove, told Westlake, 'they told us they used in their native state to make fire by rubbing two pieces of wood together' ${ }^{78}$ Mrs Hughes and Mrs Smith of the D'Entrecasteaux Channel, and the former Premier Thomas Reibey, also agreed that the Aborigines made fire 'rubbing two sticks together'. ${ }^{79}$ In Launceston, Henry Button said the Aborigines made '[f]ire by rapidly rubbing stick', while Drake, on whose south coast farm

\footnotetext{
Westlake 'Notebook 4': 107, 112.

Westlake 'Notebook 2': 49.

74. Westlake 'Notebook $4^{\prime}: 82$. Riley described using charcoal (Westlake 'Notebook $4^{\prime}: 82$ ). This is similar to Philip Thomas' powder-like 'ashes from a pipe' and Bonwick's 'powdered charcoal' that was also added to the worked groove (Westlake 'Notebook 3': 87-88; Bonwick 1870: 20). Philip Jones notes that Arnhem Land fire-makers used a speck of charcoal in their fire-drills; in Bunbury, in south-western Australia, they added dried flowers from the grass tree, while in southern Victoria frayed bark fibre was 'blown into a flame' (Jones 2008: 19, 26, 30).

75. Westlake 'Notebook 4': 32 . Beeton had said a 'dried sap' from a 'particular kind of tree' was added to the groove, while GW Knight explained that the Aborigines twirled the fire-drill, and 'at the same time' they 'blow'd with their mouth' and also used 'a dry wood dust (such as might be got from old wattle trees)' to catch the spark (Westlake 'Notebook 3': 89-90).

76. Westlake 'Notebook 5': 30 .

77. Westlake 'Notebook 4': 109.

78. Westlake 'Notebook 6 ': 43

79. Westlake ‘Notebook 2': 31; ‘Notebook 3': 58-59; 'Notebook 3': 68, 71.
} 
Westlake stayed, thought the Aborigines 'used to make a fire with two pieces of wood (not more) $)^{80}$

There are, however, several descriptions in Westlake's interviews for making fire by rubbing sticks across each other rather than in a groove. Fanny Cochrane Smith's son, Tasman, described by Westlake as a 'very good witness', explained that one 'got two really dried sticks and rubbed them together till got a light. Really dry wood. Think peppermint not certain. Seen mother when a baby ... do it. Just done by rubbing it across. Not in a groove according to mother'. Westlake then noted: 'Mrs Robt Polly at [Oyster Cove] said the same' ${ }^{81}$ Tasman's brother, Frederick Smith agreed, telling Westlake, 'I think they could get fire by rubbing two sticks. Two dry sticks and rub them across one another - never heard of groove' ${ }^{82}$ George Davis of the D'Entrecasteaux Channel told Westlake that the Aborigines made fire by getting 'two pieces of Dry Teatree' and 'rub two sticks together on their sides' ${ }^{83}$ Henry Denne also thought that fire was made 'by rubbing two sticks together' - to which Westlake added a picture of two sticks across each other forming an $X^{84}$

There are differences in opinion and detail in Westlake's interviews regarding the friction method of fire making - the several kinds of wood and additives to help ignite a flame - charcoal, 'fluff', wood dust and sap - and whether the woods were rubbed forward and backward, twirled or across each other. But one consistency runs throughout the answers Westlake gathered: all the informants concur that the Aborigines could make fire, and most agree it was by a friction method.

\section{Absence of evidence is not evidence of absence}

Westlake's papers come relatively late in the historical record. Indeed, with the notable exception of Ventenat's description, all references to the friction method date from the 1840s, although many informants' memories claim to be from earlier in the colonial period. By the 1840s, almost all the Tasmanian Aborigines - either the partners or children of the sealers, or those confined to the Flinders Island mission - were living in the Bass Strait area, where Victorian, Tasmanian and non-Aboriginal cultures intersected, and where fire-making skills may have conceivably been given to the Tasmanians for the first time. Further, several writers also consider that 'Musquito', the 'Sydney Black' who led a bushranging resistance gang in the 1820s might have also passed on new firemaking skills. ${ }^{85}$ For these reasons almost all the evidence for making fire with wood in Tasmania is generally deemed unreliable. Gott concludes that 'virtually all of [the evi-

80. Westlake 'Notebook 3': 24 .

81. Westlake 'Notebook 6': 54 . Westlake later noted from Tasman Smith: 'Fire used very hard and dry sticks. I'm always [sic] understood that one was held still and the other was rubbed straight across'; Westlake 'Notebook 6': 60.

82. Westlake 'Notebook 6': 82.

83. Westlake 'Notebook 6': 23 .

84. Westlake 'Notebook 6': 106. In another variation, James Galagher, another Channel resident, told Westlake that the Aborigines 'got fire by twirling a crooked stick like handles of a ground stone'. Westlake seemed to doubt this description, adding the question 'Australian?' next to a sketch he made and further noting that the 94-year-old was renowned as 'a great liar' (Westlake 'Notebook 6': 101).

85. Gott (2000: 4) quotes C Lord; Sculthorpe 1990: 35. Walker suggests that another 'drill' method may have been learnt by 'Australians' (Walker 1900: 5). 
dence for fire making] is open to the objection that it could have been learned from contact', especially considering the 'mixed nature of the Bass Strait communities'.$^{86}$ Although apparently not mentioned previously in this context, it is also pertinent to consider the possible influence of the seven New South Wales Aboriginal men who were employed to assist in capturing Tasmanian Aborigines between 1829 and 1831, initially by John Batman and later by Anthony Cottrell and GA Robinson. ${ }^{87}$

While south-eastern Australian Aborigines may have passed on their knowledge of fire making to Tasmanian Aborigines from about the 1810s to the 1830s, seemingly no writer has questioned the feasibility of these transactions. As it has been noted, the Aboriginal women in the Bass Strait might have taught their sealer partners how to make fire. It is conceivable that one or more of these women were from what later became Victoria. But how possible was it for this potentially Victorian knowledge to then filter to, and spread across, mainland Tasmania so that a range of Europeans, such as Davies, Rayner and Cotton could witness (or at least hear about) this method there, possibly from early in the colonial period, and assume it was Indigenous? It is perhaps more conceivable that Musquito may have passed on his knowledge of fire making via his group of Tasmanian Aborigines who ranged the country between Risdon and Pittwater in the early $1820 \mathrm{~s} .{ }^{88}$ But could one man, during the tumult of this period, plausibly have passed on his knowledge of fire making to all the other Tasmanian Aboriginal people whom Europeans saw make fire? This seems more likely than the seven New South Wales Aboriginal men passing on their knowledge of fire making. During the one to two years they were engaged to assist in the Black War, they only came in contact with the Tasmanians as assistants to their captors. It is possible that fire making might have been witnessed by Tasmanians in such meetings, but it is unlikely that these were appropriate settings for such an exchange to take place. Indeed the opportunities for different Tasmanian Aboriginal groups to meet and reciprocally share new skills such as fire making may have been equally sparse during this time.

In Philip Jones's study of fire making across Australia, many descriptions are very similar to those recorded in Roth, Westlake and other accounts, especially the fire-drill and stick-and-groove methods. While this may suggest that the Tasmanians learnt these techniques from south-eastern Australian Aborigines, it may also reinforce the validity of the Tasmanian practices. It is possible that south-eastern Australian Aborigines may have influenced how Tasmanian Aborigines made fire rather than passed on a completely new skill. The description Mr Blyth offered to Westlake of an 'old way' of making fire suggests that change did take place, but it also reinforces the idea of a precontact method. While a new variation might have been learned from Aborigines from outside Tasmania, tribal groups within Tasmania who previously might have had relatively little contact with each other until the tumult of colonisation, may also have

86. Gott, personal communication with author, 17 July 2001.

87. Campbell 1987: 30, 57-61. These seven men included Warrora (or John Pigeon), Yunbai (or John Crook) who worked for John Batman from 1829 and Macher (or Mackey) Willang (or John Stewart), Quanmerner (or Joe the Marine) and William who arrived between 1830-1831. With the exception of William, these five men continued to work for Batman after his departure to Port Phillip in 1835.

88. Ryan 1996: 79, 87. 
shared their own specific fire-making techniques, and considered the learned variations 'new'.

Westlake recorded several eye-witness accounts, which admittedly do not date from explorers or early colonists, but Plomley, in 1993, agreed that the Westlake papers include testimonies of people who 'saw the Tasmanians while some of the fullbloods ... were still alive and held views on firemaking by the natural Aborigines'. Plomley concurs with Breen that the 'burden of proof' should not rest with historical characters 'unable to present their case'. 'To fail to observe something', Plomley concludes, 'is far from claiming that it did not happen'. ${ }^{89}$ Even so, Plomley in 1966 and Jones in 1977 put more faith in the one entry in GA Robinson's journal of 28 December 1831, because it appeared to be testimony from a man who had spent more time than any other European with traditional Tasmanian Aborigines. This is true, but does Robinson's journal entry in fact state the Aborigines could not make fire?

\section{'No more was the fire lost in our land'}

In his 1992 article, Shayne Breen points out that the people Robinson travelled with were often unwilling to tell him everything about their culture, and often deceived him with misinformation. Breen imagines what knowledge Mannalargenna and Woorady might have been protecting and wonders 'if the carrying of firesticks was restricted to initiated men' (since the 'chief always' carried it), then perhaps so too was fire making. Breen wonders if fire was made in a 'special ceremony' in which the myth they spoke of - 'Parpeder' and the 'two men in the sky' - was 're-enacted' ${ }^{90}$ Breen also mentions another reference in Robinson to Aboriginal women using hot sand to ignite grass. The sealer Munro told Robinson that he, with another man, wanted to capture a young Aboriginal woman from Preservation Island. They had seen the smoke from her fire, so went to get her. When they got there, she hid, so they put out her fire with seaweed, knowing that 'as black women will obtain fire from the hot sand by means of grass; when her fire was out she must either come to the boat or go back to Gun Carriage'. Munro had set a trap: if the girl returned to the sand to get fire, she would be caught. That 'black women will obtain fire' may imply that men make it another way and further that the girl in the story did not have the 'authority'. ${ }^{91}$

Brough Smyth noted that among Victorian Aboriginal people it was 'probably that experts only used the sticks for getting fire'. Should a smaller group of Aborigines leave the main camp 'unaccompanied by fighting men' they may 'have had often to endure cold, when by carelessness or accident the fire they carried was extinguished' ${ }^{92}$ Philip Jones notes that in some Australian Aboriginal communities both men and women made fire, but in others 'it seems that only men had the right to make it'. Jones wonders if the origins for this division are found in several Australian Dreaming stories in which women first had fire, but it was wrested from them by men, who then owned the art of making it. Jones points to a translation of a funeral ceremony from western

89. Plomley 1993: 270; Breen 1992: 40; Gott 2002, the title of which is 'Absence of evidence is not evidence of absence'.

90. Breen 1992: 42.

91. Breen 1992: 42

92. Brough Smyth 1878: 396. 
New South Wales in which it was said that 'women can make no fires'. Jones considers whether this knowledge was also limited to adults, noting that in northern New South Wales, Langloh Parker wrote in 1905 that 'no Kamilaroi boy who had not been to a Boorah [initiation ceremony] would dare to try to make fire,.$^{93}$

While Breen reads Robinson's journal entry of 28 December 1831 and assumes these people are reticent in divulging details of a sacred ritual, Rhys Jones and Plomley (in 1966) assume they are wilfully demonstrating their ignorance. This ignorance is presumed not only by Mannalargenna's explanation of having to eat raw meat and look for fire from another mob if his fire brand were extinguished, but by his reference to the 'two men in the sky' and by Woorady's 'Parpeder' who 'first gave the natives fire'. It is as if the sky were the only source of fire, in the form of lightning, while the Aborigines had no artificial means to make it. The same conclusion was drawn by other contemporary writers who recorded the fire myth. James Backhouse and George Walker, two English Quakers who were sent to observe and report on the conditions in the Australian colonies from 1832 to 1838 , noted that:

the aborigines of [Van Diemen's Land] had no method of obtaining fire before their acquaintance with Europeans. They say they first obtained it from the sky, probably by this meaning from lightning. They preserved it by carrying firesticks with them. ${ }^{94}$

In his subsequent book, A Narrative of a Visit to the Australian Colonies, Backhouse attributes this story to the Aboriginal man Proper who travelled with the missionaries from Launceston to Flinders Island, although Gott wonders if the statement might in fact have come from Darling, the mission's superintendent. ${ }^{95}$

Lieutenant Pascoe, who visited Flinders Island from 1837 to 1843, told James Backhouse Walker that he was once 'out with a black on a mountain in Flinders' when he asked the Aboriginal person to 'make fire by rubbing wood'. 'The black', however, 'could not understand him' and said 'star tumble down, make fire'. ${ }^{96}$ That the sky was the only source of fire for the Tasmanian Aborigines is also echoed decades later in the words of Mrs Sarah Miller, the daughter of Fanny Cochrane Smith, who told Westlake in 1910:

Father used to question them how they had fire. [Flint and steel and dried punk off the tree.] All that ever they could tell him was that their 'father give it them' they believed very much in a supreme being. This was always their belief before meeting the whites. I can remember Trucanini and she said could never give any account of how they got fire ... Fire was always carried about by them. The first thing at a camp was light a fire and keep it going till they had to start again. Punk is a white fungus in sheets ... Never ... hear mother or father say that used to get fire by getting rubbing pieces of wood together, but only in questioning older natives heard them say that their 'father give it them'. ${ }^{97}$

93. Jones 2008: 9.

94. Plomley 1987: 241. Backhouse reiterates this point in his Flinders Island diary: 'they kept their fire by carrying ignited sticks with them wherever they went. It is said they first obtained fire by the effect of lightning' (Plomley 1987: 230).

95. Backhouse 1843: 99; Gott 2002: 653.

96. Roth 1899: 84.

97. Westlake 'Notebook 6': 114-115. 
Mrs Miller remembers the customs of the 'older natives' by recalling their tradition of talking about the fire myth whenever questioned about how it was made. Just as Woorady told Robinson 'PARPEDER gave fire', Mrs Miller tells Westlake 'Father give it to them' - a 'supreme being'. Just as Breen suggests Mannalargenna and Woorady (who came from the same country as Trukanini) were purposefully oblique in their answers to Robinson on fire making, so perhaps is Mrs Miller in response to Westlake's questions. Given her detailed knowledge of native foods and spiritual customs, she may have known how fire was traditionally made, but also did not want to tell. Moreover, her brothers, Tasman and Fred Smith, clearly remembered how they thought their traditional Aboriginal ancestors made fire - by rubbing two sticks across each other; Tasman Smith also remembered seeing his mother doing this. While Mrs Miller does not mention this, she does describe fire being made with 'Flint and steel and dried punk off the tree' ${ }^{98}$

It is also possible that the meaning of the fire myth has been repeatedly misinterpreted. A more complete version of the myth appears in Joseph Milligan's 1859 article in the Papers and Proceedings of the Royal Society of Tasmania, reproduced by Roth, in which the following 'legend' was 'related by a native of the Oyster Bay tribe':

My father, my grandfather, all of them lived a long time ago, all over the country; they had no fire. Two black fellows came ... on the summit of a hill they were seen by my fathers, my countrymen ... seen standing: they threw fire like a star - it fell among the black men, my countrymen. They were frightened - they fled away ... after a while they returned - they hastened and made a fire - a fire with wood; no more was the fire lost in our land. The two black fellows are in the clouds: in the clear night you see them like two stars. ${ }^{99}$

This appears to be similar to the story Mannalargenna told Robinson in which 'two men in the sky first gave the natives fire'. It may also be the same story told by Proper to Backhouse and Walker, by 'the black' of Flinders Island to Dove and by Trukanini, and the 'older natives' to Mrs Miller's father. This legend points to a Dreaming time 'a long time ago' when Aborigines had no fire, in contrast to their present time with fire. As Woorady, Mannalargenna and Proper apparently said, this story refers to the 'first' time their people got fire, but not necessarily how they continued to get it. At that initial moment of seeing fire the people fled in fear, but 'they returned - they hastened and made a fire - a fire with wood'. After this initial 'fire with wood' was made, 'no more was the fire lost in our land'. Was the 'fire with wood' made by lighting a fire stick or by creating a fire with two pieces of wood? This crucial difference could easily have been lost in the confusion of translation, or may have been purposefully left obscure. We do not know what the Aborigines - whether the 'native of the Oyster Bay tribe', or Mannalargenna, Woorady or Proper - actually said; nor do we know what questions they were attempting to answer; nor how well the parties understood one another.

98. Plomley has excised the note made by Westlake in square parentheses without indication. His edited version of Mrs Miller's statement opens as: 'Father used to question them how they had fire. All they could ever tell him was that their "father gave it them" (they believed very much in a supreme being)' (Plomley 1991: 61).

99. Roth 1899: 84-85; Milligan 1859: 274. 
Myths for the origin of fire from around the world predominantly refer to fire first coming from the sky. In Greek mythology Prometheus steals fire from Jupiter, and brings it to earth. There are also Dreaming stories across Aboriginal Australia that tell of fire coming from the sun, or from a bird in the sky, although most refer to fire coming from the land. However, Philip Jones explains that the stories all share, to a degree, a 'common structure', also found in the Tasmanian fire legend:

Fire, and the secret of making it, was once in the possession of an individual, or a privileged few. Its subsequent theft, by a covetous individual, leads to the inadvertent release of fire into the landscape, so that it becomes available to all people. ${ }^{100}$

This idea of a 'secret' of fire making may have been remembered in some Aboriginal cultures, including Tasmania, where only one group of people had the authority to make it. Tylor observed that, because of the preponderance of 'Prometheus-legends' around the world, the idea of fireless peoples is another myth that has been promulgated for 'ages' with Tasmania being only a recent example. The very idea of a fireless people would, Tylor admitted, 'be of the highest interest to the ethnographer' as it would demonstrate an important evolutionary step to those 'races who can produce fire', especially since making fire is, in his opinion 'an art which, once learnt, would hardly be lost' (although Rhys Jones considered that it could be). Tylor was unconvinced that any known peoples were unable to make fire, and that any such claim had always been made 'without any sound basis' ${ }^{101}$ Brough Smyth agreed with Tylor, stating that observers such as Dove had not considered the importance of their statements, nor provided sufficient evidence. He noted that while it is considered proper in Europe to describe [the Tasmanians] as the most degraded amongst all the races of mankind', the 'skill' they displayed in other aspects of their lives 'would lead one to suppose that the art of making fire was known to them as to other savage peoples in a similar condition'. ${ }^{102}$

\section{Fire in the rain}

All these considerations point to why Robinson's journal entry of 28 December 1831 is not an incontrovertible statement that the Tasmanian Aborigines could not make fire. But there may be another, far more mundane, reason that he did not see it being made: the passage is qualified by the clause 'They said if their fire went out by reason of rain'.

Making fire might have been impossible in wet and cold weather. ${ }^{103}$ Melville, writing in 1851, thought the Aborigines made fire by rubbing a stick in a groove of wood, but added that 'it was difficult at times to obtain fire by this means, especially in wet weather' ${ }^{104}$ William Buckley, who lived with the Victorian Wathaurang from 1802 to 1836, found making fire in winter almost impossible:

In summer months fire is very easily obtained by rubbing together two sticks they call Dealwark. They sometimes carry these unlighted fire-sticks about with them,

\footnotetext{
100. Jones 2008: 3.

101. Tylor 1964: 249.

102. Brough Smyth 1878: 397.

103. Ian Hunter, a Wurundjeri man from Victoria, told Beth Gott it was impossible to make fire using wood in wet and cold conditions (Gott 2002: 651).

104. Roth 1899: 84.
} 
wrapped in a sort of covering made of opossum hair. In the winter months they are often much distressed for fire, and suffer greatly from hunger and cold. ${ }^{105}$

It was late December - summer - when Robinson asked the Aborigines what happened if rain doused their fire brands. They were walking near Lake Echo in the lakes region of Tasmania's central plateau. It is rarely hot there and often raining. On 12 and 13 December 1831 Robinson recorded there had been rain, snow and hail. Two days later it snowed again, and hailed the day after that. From 18 to 20 December there were heavy winds and rain. Pleasant weather persisted for another five days, and then two days before Robinson asked the question about fire making, it was again wet and windy.

The difficulty of making fire in Tasmania led James Calder to conclude the Tasmanian Aborigines were 'ignorant of any method of procuring fire', since he thought, 'no amount of friction could possibly ignite the woods of this colony'. ${ }^{106}$ James Fenton assumed Calder was referring to the hardness of Tasmanian woods, asserting in 1884 that the Aborigines 'were ignorant of any artificial means of procuring fire: indeed it would be difficult to ignite the hard woods of the island by friction' ${ }^{107}$ Roth, possibly assuming that Calder was referring to the wetness of Tasmanian woods, stated that the Aborigines made fire with timber, but that 'ignition could probably only be produced in hot dry weather' ${ }^{108}$

Fire brands, made out of slow burning tinder, such as bark, were designed to burn for a long time and stay alight even while travelling on water rafts or in wet weather. ${ }^{109}$ On 9 November 1831, Robinson had found it

amusing to see the chief in the heavy rain naked walking in advance ... streaming his lighted torch against the wind and the rain. As I was acquainted with its meaning it was the more amusing. This experiment was intended to stop the rain. ${ }^{110}$

Thomas Bock's painting of Mannalargenna shows him holding a smouldering fire brand. Melville wrote that the Aborigines 'generally, in their peregrinations, carried with them a fire-stick, lighted at their last encampment' ${ }^{111}$ Scott, Fenton and Jorgenson made similar observations. ${ }^{112}$ Thomas Dunabin told Westlake that the Aborigines had to 'to work very hard', to get fire, adding that 'old hands say this was the last resort; would always carry a piece of fire'. Other informants agreed that the Aborigines would never let their fire brands expire. ${ }^{113}$ Philip Jones quotes Surveyor Robert Austin who recalled of the Pindjarup people of south-western Australia (a similarly wet area in winter): 'If the necessary timber for manufacturing these firesticks ever proved at all unsuitable through wet, or scarce, the lighted sticks would be carried along under the

\footnotetext{
105. Jones 2008: 4; Gott 2002: 652; Morgan 1967: 68; Brough Smyth 1878: 396.

106. Roth 1899: 83.

107. Fenton 1884: 94

108. Roth 1899: 83.

109. Roth 1899: 84.

110. Plomley 1966: 509.

111. Roth 1899: 84.

112. Scott 1873: 25; Fenton 1884: 94; Breen 1992: 41.

113. Westlake 'Notebook 4': 109, 32, 101; 'Notebook 3': 59.
} 
men's or women's cloaks'. A small fire was kept burning in every Aboriginal camp, and women lit fire-sticks from these fires to carry when the group moved on. ${ }^{114}$

Since it was so common for Aboriginal people to carry burning fire sticks, it was not unusual for observers to never see fire being made. Brough Smyth noted that Victorian Aboriginal men and women 'always carried a lighted ... brand' when they left their camp, and that 'consequently ... white men who have lived with the Aborigines, and who have become acquainted with many of their practices, are unable to say how fire is procured' other than to 'state vaguely that two sticks are rubbed together'. ${ }^{115}$ This was even the case in drier regions of Australia. Philip Jones explains that during the Elder expedition into Western Australia from 1891 to 1892, Helms observed that all the Aboriginal groups they encountered carried fire sticks, but he failed to convince any of them to show him how fire was made. In their case, soft, pithy materials, such as the grass tree, were unavailable. ${ }^{116}$ This may explain why Robinson first saw fire being made by Aboriginal people in Victoria.

It was not only the Tasmanians who had to travel to another group to get fire if their fire sticks were extinguished. Echoing Mannalargenna's words to Robinson, William Buckley in Port Phillip found that if his group's fire sticks went out while travelling, they had to wait until they could find another mob with fire so 'we were again able to make fires to cook our food' ${ }^{117}$ Anthropologist Norman Tindale found that Aboriginal people in South Australia's Adelaide Plains and Eyre and Yorke Peninsulas sometimes had to travel long distances to replenish their fire. ${ }^{118}$ Even in Lake Eyre, one of the driest regions of Australia, missionary JG Reuther recorded these phrases from the Aboriginal people of Lake Eyre: 'kindle (rub) a fire today; tomorrow the wood may be damp' and 'come here with your firestick; the rain has extinguished my fire', meaning the 'obligation to provide fire was undoubtedly strong; to refuse to comply with this request would certainly jeopardise relations' ${ }^{119}$ As Mannalargenna told Robinson: 'They must give fire and sometimes they would fight afterwards'.

Philip Jones considers that if Aboriginal people in wetter regions of southern Australia were temporarily unable to make fire, then it is conceivable that 'local conflict or shifts in alliances' could lead to people being unable obtain fire from their neighbours, and therefore 'fire-making skills could gradually diminish within an expanding region, ultimately to the limits of islands such as Kangaroo Island or Tasmania'. ${ }^{120}$ This is essentially Rhys Jones' thesis: that people isolated from potential new ideas, could, over several generations, lose essential skills and technologies.

While this may be a possibility, particularly in Tasmania where Aboriginal people were seemingly unable to make fire in wetter seasons and regions, there is equally no conclusive evidence that they had completely lost the skill. Sylvia Hallam warns 'that the use of a fire-brand did not signify inability to ignite a fire'. ${ }^{121}$ To state that the Tas-

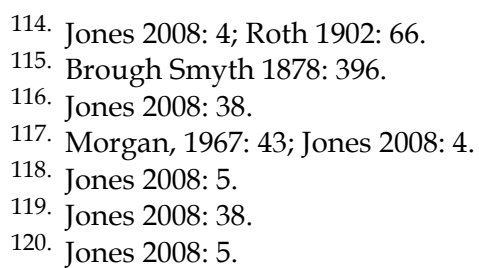


manian Aborigines could not make fire in the rain is quite different to stating that they had forgotten or never knew how to make it.

\section{Contrasting images}

Notwithstanding evidence to the contrary, it was Rhys Jones' passionate and energetic prose that captured and then persuaded a wide audience into accepting as fact his argument that Tasmanian Aborigines could not make fire. Perhaps Jones cast aside the contrary evidence not only because he was convinced by Plomley's footnote, but because he was seduced by the very idea of a fireless people. The hypothesis fitted into, and indeed helped shape, his vision of a society in cultural decline due to their biogeographical isolation. The smouldering fire stick for Jones symbolised, on the one hand, a traditional society unable to make fire, while on the other hand, it was the tool he imagined the Tasmanian Aborigines used to control and manage their landscape. It was Jones, after all, who coined the term 'fire-stick farming' in a famous article from 1969, a term that is now part of the Australian lexicon. That article popularised the notion that for hundreds of generations Aborigines had deliberately set fire to their land to clear it for hunting, gathering, travelling and living, an idea foreshadowed by Tindale in 1959, and extended by Hallam in 1975. ${ }^{122}$ While Jones considered the practice universal to Australia, he was first inspired by his research in Tasmania; from Robinson's journals, Jones learned that the Aborigines 'set fire to the bush as they walked along'. ${ }^{123}$ The first page of Jones's 1969 article carries Bock's painting of Mannalargenna with his fire stick.

It makes a degree of sense that a people who could not create a flame would make wide use of fire, since with perpetually-burning fire there is far less risk of it being completely extinguished. It then follows that, without a need to make fire, the art of making it would, in time, be lost. What emerges from this logic, however, are two contrasting pictures of traditional Tasmanian Aboriginal life: a people with power over their land and a people passively at its mercy. In 1969 Jones allows Mannalargenna control over his land with fire, but a few years later, in 1977, he is denied the ability to make it. ${ }^{124}$ But in both contrasting pictures Jones offered radical and ground-breaking new pictures of Aboriginal Tasmania. As John Mulvaney reflects, Jones, by introducing the idea of firestick farming, allowed white Australians to see Aboriginal people not as passive nomads, but as active shapers of their world. ${ }^{125}$ But in the case of Tasmanian Aborigi-

121. Hallam 1975: 44; Jones 2008: 5. Breen also makes this point: 'if one reason for carrying fire was to preserve it, this should not be taken as evidence that the Tasmanians could not make it' (Breen 1992: 41).

122. Jones 1969: 224-228. Tindale wrote that: '[M]an probably has had a significant hand in the moulding of the present configuration of parts of Australia. Indeed much of the grassland of Australia could have been brought into being as a result of his exploitation'. Tindale continues that firing the land may also have had such 'a profound effect on the distributions of forest ... that true primaeval forest may be far less common in Australia than is generally realised' (Tindale 1959: 36-51). Hallam, with tribute to Jones, extended his notion of 'fire-stick farming' arguing that the parklands that the first European settlers found ideal for grazing had been created by Aboriginal fire regimes (Hallam 1975: 71-77). For further discussion, see Horton 2000: 70-101, who argues that the 'fire-stick farming' thesis put forward by Tindale, Jones and Hallam is fundamentally flawed.

123. Harris 2001: 55-60; Mulvaney 2001: 19-22.

124. Jones 1969, 1977a. 
nes, Jones found evidence that defied the base rule of progression in evolutionary theory. For Jones the Tasmanian Aborigines were a fireless people; and thus represented a culture in slow degenerative decline. While anthropologists such as Roth and Tylor had considered the Tasmanian Aborigines 'rude savages', as Tylor put it, both insisted they could make fire. For Tylor and Roth, the Tasmanian Aborigines were modern representatives of Palaeolithic man, and thus represented a cultural evolutionary beginning. ${ }^{126}$

\section{Conclusion}

Almost all the historical sources on fire making from as early as 1773 support the idea that the Tasmanian Aborigines made fire. The few 19th century sources to state that they could not were evidently influenced either by a Tasmanian Aboriginal myth in which fire is said to come from the sky (Milligan, Dove, Backhouse and Walker) or by the hardness, and possibly wetness, of Tasmanian timbers (Calder and Fenton). Both of these factors make Robinson's journal entry in late 1831 highly ambiguous: Mannalargenna was perhaps unwilling to divulge what may have been a secret ritual related to a mythical story, or was unable to make fire in the rain, or both.

It was not, however, until the late 19th or early 20th century that Tasmanians, recorded by Walker and by Westlake, testify to having seen traditional Tasmanian Aborigines making fire. It is for this reason that Gott and Sculthorpe, among others, consider it plausible that the Tasmanian Aborigines may have learned to make fire from south-eastern Australian Aborigines after colonisation. For this to be possible, however, a small number of outsider Aborigines must have been able to disseminate quickly their fire-making knowledge to different parts of Tasmania, predominantly during an extremely tumultuous time in the colonial period. Moreover, the French and English explorers must have all been mistaken in their explanations of the stones they found carefully stored in baskets - a collective interpretation that Plomley considered, in 1993, to be 'impressive'. Moreover, as Gott, Breen and Plomley (following Breen) note, just because fire making was not witnessed earlier in Tasmania's historical record, does not mean the Aboriginal people could not make it.

Plomley's revised opinion was informed in part by his own reappraisal of Westlake's informants as important and reliable sources of traditional Tasmanian Aboriginal culture. Sculthorpe notes that Westlake's reports make it possible that fire was made in Tasmania using a grass-tree drill, albeit a technique that might have been introduced by south-eastern Australian Aboriginal people. ${ }^{127}$ The continuity in fire-making

125. Mulvaney, 2001: 20, 21.

126. William Flower (1878) foreshadowed the idea that the Tasmanian Aborigines may have degenerated. In the late 1920s to mid-1930s Henry Balfour, Curator of the Pitt Rivers Museum, pre-empted Jones' thesis of cultural degeneration in an unpublished manuscript, 'Stone Implements of the Natives of Tasmania'. He wrote: 'The Tasmanians must have become isolated and immune to culture-contacts, when Bass Straits were formed ... This culture remained stagnating and may even possibly have retrogressed'. It is possible that Jones, who according to the museum's correspondence files read this manuscript, may have been (if unwittingly) influenced by it, although he does not reference Balfour in his later work (Balfour c1930: 6; Jones, letter to Derek Roe, 3 May 1966).

127. Sculthorpe 1990: 36 . 
descriptions from Walker's informants using such a method (and other earlier sources) to Westlake's is indeed noteworthy. It is most obvious in the interviews with Aboriginal Islanders by whom this information had possibly been inherited along with other Indigenous traditions. As I argued in 'The polemics of eating fish in Tasmania', these testimonies should be given a sympathetic hearing not only because it is respectful to Tasmanian Aboriginal people, but because it is also scholarly to do so. The Aboriginal (and non-Aboriginal) testimonies on making fire in the Westlake papers add considerable weight to an already large body of corresponding historical evidence that overwhelms the sparse and ambiguous contrary sources.

However, Plomley's 1966 conclusion that the Tasmanian Aborigines could not make fire has had a far-reaching impact. It convinced Rhys Jones whose ground-breaking archaeological work influenced almost all subsequent scholarly work on Aboriginal Tasmania. But the idea that the Tasmanian Aborigines could not make fire was never more than supposition. ${ }^{128}$ While the contrasting claim that they could make fire has never been an absolute certainty, it is the far more logical and probable conclusion.

\section{References}

\section{Primary sources}

Balfour, Henry c1930, 'Stone implements of the Natives of Tasmania', Balfour Papers, Pitt Rivers Museum Manuscript Collections, University of Oxford: box 6 .

Gott, Beth 2000, 'Absence of evidence is not evidence of absence - fire-making in Tasmania', unpublished, Melbourne.

- 17 July 2001, Email to Rebe Taylor, Australian National University, Canberra. Jones, Philip 2008, 'Aboriginal fire', unpublished, Adelaide.

Jones, Rhys 3 May 1966, Letter to Derek Roe, Related Documents File 1934.83-86, Pitt Rivers Museum, University of Oxford.

Ryan, Lyndall 4 November 2008, Email to Rebe Taylor, University of Melbourne.

Taylor, Rebe 2004, 'Island Echoes: Two Tasmanian Aboriginal Histories', PhD thesis, Australian National University, Canberra.

Walker, James Backhouse, Correspondence to Henry Ling Roth, 1891-1899 in Ling Roth, Henry 1919: 'The Aborigines of Tasmania: Papers, Printed Pamphlets, Original MSS, Letters, Photographs, Books, Prints ...', Manchester Museum.

— 13 August 1976, 'Biographical Notes on Ernest Westlake', Westlake Papers, Manuscripts Collection, Pitt Rivers Museum, University of Oxford: box 1, folder $2 b$, ff. 27-29.

Westlake, Ernest 1908-1910, Correspondence to Margaret and Aubrey Westlake, Westlake Papers, Manuscripts Collection, Pitt Rivers Museum, University of Oxford: box 1, folder 1a, ff. 1-271.

- Notebooks 1-6, 1908-1910, Westlake Papers, Manuscripts Collection, Pitt Rivers Museum, University of Oxford: Box 1.

128. Breen 1992: 41; Tylor 1964: 249. 


\section{Secondary sources}

Backhouse, James 1843, A Narrative of a Visit to the Australian Colonies, Hamilton Adams, London.

La Billardière, Jacques-Julien Houtou de 1800, Voyage in Search of La Perouse, Performed by Order of the Constituent Assembly, During the Years 1791, 1792, 1793, and 1794, [microform], printed for John Stockdale, London.

Bennet, S 1980, 'A home in the colonies: Edward Braddon's letters to India from northwest Tasmania, 1878', Tasmanian Historical Research Association Papers and Proceedings 27: 119-216.

Bonwick, James 1870, The Last of the Tasmanians or the Black War of Van Diemen's Land, Sampson Low, Son \& Marsted, London.

Breen, Shayne 1992, 'Tasmanian Aborigines - making fire', Tasmanian Historical Research Association Papers and Proceedings 39(1): 40-43.

Bryden, William 1960, The Story of the Tasmanian Aboriginals, Tasmanian Museum and Art Gallery, Hobart.

Campbell, AH 1987, John Batman and the Aborigines, Kibble, Malmsbury.

Diamond, Jared 1993, 'Ten thousand years of solitude', Discover 14(3): 48-57.

Dove, Rev T 1842, 'Moral and social characteristics of Aborigines of Tasmanian as gathered from intercourse with the surviving remnants of them now located on Flinders Island', The Tasmanian Journal of Natural Science 1: 247-255.

Fenton, James 1884, A History of Tasmania, Macmillan, Birchall, Roberston \& Co, Sydney, Melbourne, Adelaide, Launceston, London.

Flannery, Tim 1994, The Future Eaters, Reed New Holland, Sydney.

Flower, William H 1878, 'The Aborigines of Tasmania an extinct race: a lecture delivered in the Hulme Town Hall, Manchester, Nov. 30 1878', Science Lectures for the People Delivered in Manchester 1877-78-79, Ninth and Tenth Series, John Heywood, Manchester.

Giblin, LF 1927, Handbook to Tasmania, prepared for the members of the Australasian Association for the Advancement of Science on the occasion of its meeting in Hobart, January 1928, Government Printer, Hobart.

Gott, Beth 2002, 'Fire-making in Tasmania: absence of evidence is not evidence of absence', Current Anthropology 43(4): 650-657.

Hallam, Sylvia 1975, Fire and Hearth: A Study of Aboriginal Usage and European Usurpation in South-western Australia, Australian Institute for Aboriginal Studies, Canberra.

Harris, David 2001, 'People, land, fire and food: comments on two Jonesian themes', in Atholl Anderson, Ian Lilley and Sue O'Connor (eds), Histories of Old Ages: Essays in Honour of Rhys Jones, Pandanus Books, Canberra: 55-60.

Haydon, Tom 1978. The Last Tasmanian, Artis Film Productions.

Horton, David 2000, The Pure State of Nature, Allen \& Unwin, St Leonards.

Jones, Rhys 1969, 'Fire-stick farming', Australian Natural History, 16 (7): 224-228.

— 1977a, 'The Tasmanian paradox', in RVS Wright (ed), Stone Tools as Cultural Markers, Australian Institute for Aboriginal Studies, Canberra: 189-204.

- 1977b, 'Man as an element of a continental fauna: the case of the sundering of the Bassian Bridge', in Jim Allen, Jack Golson and Rhys Jones (eds), Sunda and Sahul: 
Prehistoric Studies in Southeast Asia, Melanesia and Australia, Academic Press, London, New York, San Francisco: 317-386.

— 1978, 'Why did the Tasmanians stop eating fish?', in RA Gould (ed), Explorations in Ethnoarchaeology, University of New Mexico Press, Albequerque: 11-47.

- 1987a, 'Hunting forebears', in M Roe (ed), The Flow of Culture: Tasmanian Studies, Australian Academy of the Humanities, Canberra: 12-49.

— 1987b, 'Ice-age hunters of the Tasmanian wilderness', Australian Geographic (August): 26-45.

Lubbock, Sir John 1878, Pre-historic Times, as Illustrated by Ancient Remains, and the Manners and Customs of Modern Savages, 4 th edn, Frederic Norgate, London.

Milligan, Joseph 1859, 'Vocabulary of dialects of Aboriginal tribes of Tasmania', Papers and Proceedings of the Royal Society of Tasmania 3: 239-274.

Morgan, John 1967, The Life and Adventures of William Buckley, Thirty-two Years a Wanderer amongst the Aborigines of the then Unexplored Country round Port Phillip, now the Province of Victoria, (originally published by Archibald Macdougall, Hobart, 1852), Heinemann, London, Melbourne.

Mulvaney, John 2001, 'Peopled landscapes: from prehistoric Tasmania to contemporary Arnhem Land', in Atholl Anderson, Ian Lilley and Sue O'Connor (eds), Histories of Old Ages: Essays in Honour of Rhys Jones, Pandanus Books, Canberra: 19-22.

Noetling, Fritz 1907, 'Notes on the Tasmanian Amorpholithes', Papers and Proceedings of the Royal Society of Tasmania: 1-37.

Norman, Rev. James 1910, 'Aborigines of Tasmania - the Norman vocabulary', Papers and Proceedings of the Royal Society of Tasmania: 333-342.

Plomley, NJB 1962, A List of Tasmanian Aboriginal Material in Collections in Europe, Records of the Queen Victoria Museum, Launceston.

- 1966, Friendly Mission, the Tasmanian Journals and Papers of George Augustus Robinson, 1829-1832, Tasmanian Historical Research Association, Hobart.

- 1976, A Word-list of the Tasmanian Aboriginal Languages, published by the author in association with the Government of Tasmania, Hobart.

- 1977, The Tasmanian Aborigines: A Short Account of Them and Some Aspects of Their Life, published by the author in association with the Adult Education Division, Launceston.

- 1983, The Baudin Expedition and the Tasmanian Aborigines 1802, Blubber Head Press, Hobart.

- 1987, Weep in Silence, a History of the Flinders Island Aboriginal Settlement, Blubber Head Press, Hobart.

- 1991, The Westlake Papers, Records of Interviews in Tasmania, 1908-1910, Occasional Paper No. 4, Queen Victoria Museum \& Art Gallery, Launceston.

- and J Piard-Bernier 1993, The General: The Visits of the Expedition led by Bruny d'Entrecasteaux to Tasmanian Waters in 1792 and 1793, Queen Victoria Museum, Launceston.

Rae-Ellis, Vivienne 1981, Trucanini: Queen or Traitor?, Australian Institute for Aboriginal Studies, Canberra. 
Roth, Henry Ling 1890, The Aborigines of Tasmania, Kegan Paul, Trench, Trüber \& Co, London.

- 1899, The Aborigines of Tasmania, F King \& Sons, Halifax, England.

Roth, Walter $\mathrm{E} 1902$ (?), Notes of Savage Life in the Early Days of West Australian Settlement, publisher and place of publishing not given.

Ryan, Lyndall 1996 [1981], The Aboriginal Tasmanians, Allen \& Unwin, Sydney.

Scott, James 1873, Letter to JW Agnew, Honorary Secretary, Royal Society of Tasmania, read to the Royal Society of Tasmania at the meeting held 8 July 1873: Papers $\mathcal{E}$ Proceedings of the Royal Society of Tasmania, 1873: 24-25.

Smyth, Robert Brough 1878, The Aborigines of Victoria: With Notes Relating to the Habits of the Natives of Other Parts of Australia and Tasmania, vols 1-3, John Ferres, Melbourne.

Sculthorpe, Gaye 1990, 'The ethnographic collection of George Augustus Robinson', Memoirs of the Museum of Victoria 1(1): 1-96.

Taylor, John A 2003, 'Fire making by the Tasmanians Aborigines (the linguistic evidence)', unpublished, Launceston, Tasmania.

Taylor, Rebe 2007, 'The polemics of eating fish', Aboriginal History 31: 1-27.

Thomas, Tyrone 1987, 100 Walks in Tasmania, Hill of Content, Melbourne.

Tindale, Norman 1959, 'Ecology of primitive Aboriginal man in Australia', in A Keast, RL Crocker and CS Christian (eds), Biogeography and Ecology in Australia, Monographiae Biologicae, W Junk, Den Haag: 36-51.

Tylor, EB 1964, Researches into the Early History of Mankind, in P Bohannan (ed), (republished from the 3rd edition, 1878), University of Chicago Press, Chicago and London.

Völger, Gisela 1973, 'Making fire by percussion in Tasmania', Oceania 44(1): 58-63.

Walker, James Backhouse 1900, The Tasmanian Aborigines, John Vail, Government Printer, Hobart.

Windschuttle, Keith 2002, The Fabrication of Aboriginal History, Volume One, Van Diemen's Land 1803-1847, Macleay Press, Sydney. 